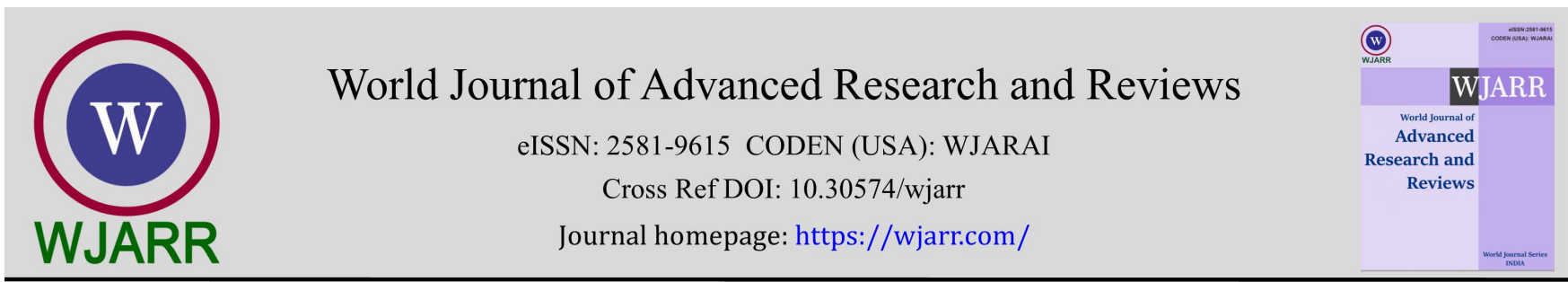

(RESEARCH ARTicle)

\title{
Effects of climate change on pests and diseases, its awareness and adaptation strategies among Cocoa farmers in Abia State
}

\author{
Michael Olusayo Okeniyi ${ }^{1,}{ }^{*}$, Temitope Seun Okeniyi ${ }^{2}$ and Fatimoh Bolanle Mustopha ${ }^{2}$ \\ ${ }^{1}$ Crop Protection Division, Cocoa Research Institute of Nigeria, Ibadan, Oyo State, Nigeria. \\ ${ }^{2}$ Economics and Statistics Division, Cocoa Research Institute of Nigeria, Ibadan, Oyo State, Nigeria.
}

World Journal of Advanced Research and Reviews, 2021, 10(03), 061-068

Publication history: Received on 10 April 2021; revised on 30 May 2021; accepted on 03 June 2021

Article DOI: https://doi.org/10.30574/wjarr.2021.10.3.0227

\begin{abstract}
The study was a survey aimed at understanding the awareness level among cocoa farmers in Abia state on climate change, its effects on Pests and Diseases of cocoa and how they adapt and mitigate the effects. A multi stage-sampling procedure was used to select 50 respondents from Bende local government area and 50 respondents from Ikwuano local government area of Abia State. Result showed that $96 \%$ of the respondents are aware that climate change has a negative effect on cocoa production as a result of high incidence of Pest and diseases and that the effect ranges from high to moderate. Majority of the respondent in the study area adopted various adaptation strategies to mitigate the effects of climate change on Pests and Diseases prevalence. High level of awareness, adaptation and coping strategies adopted by farmers, made them less vulnerable to the adverse effects of Pests and Diseases as a result of the change in climate has been currently experienced.
\end{abstract}

Keywords: Awareness; Pests and Diseases; Climate change; Adaptation strategy; Cocoa farmers

\section{Introduction}

Climate change is a global phenomenon and is increasingly becoming a worrisome issue and a threat to humanity [1]. The impact of climate change on food supply varies significantly by region and the risk is generally believed to be more acute in developing countries. Over 70\% of the country's population is engaged in agriculture as their primary means of livelihood [2, 3, 4]. The economies of many African countries largely depend on weather-sensitive agricultural production system, Nigeria inclusive and are particularly vulnerable to climate change. Nigeria climate has been changing, evident in increases in temperature; variable rainfall; rise in sea level and flooding; drought and desertification; more frequent extreme weather events; affected fresh water resources and loss of biodiversity. Agriculture produce in Nigeria is mainly rain fed and unpredictable rainfall variation makes it difficult for farmers to plan their operations $[5,6]$. Higher temperature, lower rainfall, droughts and desertification reduces farmlands, lower agricultural productivity and affects crop yields [7]. Increased rainfall intensity in the coastal region, sea level rise, flooding and erosion of farmland will also lower agricultural production [8]. Drought has also become a constant in Nigeria, and is expected to continue in Northern Nigeria, arising from a decline in precipitation and rise in temperature $[9,10]$. Reports have shown that the challenges with climate change are not the same across the country. Nigeria has a tropical climate with two precipitation regimes: low precipitation in the North and high precipitation in parts of the Southwest and Southeast [11, 4]. This vulnerability according to has been demonstrated by the devastating effects of flooding in the Niger Delta region of the country and the various prolonged droughts that are currently witnessed in some parts of Northern Nigeria region. Evidence from literature and past studied has revealed that the present global warming has influenced agricultural productivity leading to declining food production. $[12,13,14]$ showed that climate change greatly affects cocoa production both in hot and wet seasons and during irrigation. According to [15], three

\footnotetext{
${ }^{*}$ Corresponding author: Michael Olusayo Okeniyi

Crop Protection Division, Cocoa Research Institute of Nigeria, Ibadan, Oyo State, Nigeria. 
major phases mostly affected by climate change during field operations include nursery seedlings, field establishment and processing phases. Climate change also affects bio-physiological processes of both the crop and the rate of development of cocoa pests and pathogens which may result in low cocoa yield and may also impact on farmers' income and livelihood and hence increased poverty and food security [16].

\section{Methodology}

Multi-stage random sampling technique was employed in the selection of 100 respondents from two purposively selected Cocoa producing Local Government Areas of Abia State. The selected Local Government Areas include Bende and Ikwuano. Random sampling was used to select two villages from each of the two LGAs. Twenty-five farmers were randomly selected from each of the villages making a total of one hundred respondents of which only Ninety-six were found suitable for the analysis. Structured questionnaire was used to elicit information from the selected respondents. The information collected from the respondents was analysed using descriptive statistics to describe the socio economic characteristics of the farmers.

\section{Results and discussion}

Socio-economic characteristics of the farmers in the study area are described in Table 1 . The ages of the farmers ranges between 30 years to over fifty years. Those within the ages of 30 to 50 years were relatively young being $62.5 \%$ of the total population studied while $27 \%$ were over 50 years. The implication of this is that the substantial percentage of cocoa farmers in Abia state are relatively young which is good for cocoa production. 83.3\% of the farmers are male while $17 \%$ are female.

Table 1 Socio-economic characteristics of the farmers

\begin{tabular}{|c|c|c|}
\hline Variables & Frequency & Percentage \\
\hline \multicolumn{3}{|l|}{ Gender } \\
\hline Male & 80 & 83.33 \\
\hline Female & 16 & 16.67 \\
\hline Total & 96 & 100.00 \\
\hline \multicolumn{3}{|l|}{ Age of the farmers } \\
\hline$\leq 30$ & 10 & 10.42 \\
\hline $31-50$ & 60 & 62.50 \\
\hline$>50$ & 26 & 27.08 \\
\hline Total & 96 & 100.00 \\
\hline \multicolumn{3}{|l|}{ Marital Status } \\
\hline Single & 6 & 6.25 \\
\hline Married & 84 & 87.50 \\
\hline Divorced & 4 & 4.17 \\
\hline Widowed & 2 & 2.08 \\
\hline Total & 96 & 100.00 \\
\hline \multicolumn{3}{|c|}{ Farming experience of the farmers } \\
\hline$\leq 10$ & 6 & 6.25 \\
\hline $11-30$ & 50 & 52.08 \\
\hline$>30$ & 40 & 41.67 \\
\hline Total & 96 & 100.00 \\
\hline \multicolumn{3}{|l|}{ Level of education } \\
\hline No formal education & 36 & 37.50 \\
\hline Primary education & 28 & 29.17 \\
\hline Secondary education & 26 & 27.08 \\
\hline Tertiary education & 6 & 6.25 \\
\hline Total & 96 & 100.00 \\
\hline
\end{tabular}


Figure 1 indicates that $95 \%$ of the farmers sampled had the knowledge about climate change which enabled them to adapt and mitigate the effects of climate change on cocoa production this findings is corroborated by the report of [17] who observed that large majority of the respondents in Abia State were aware of climate change.

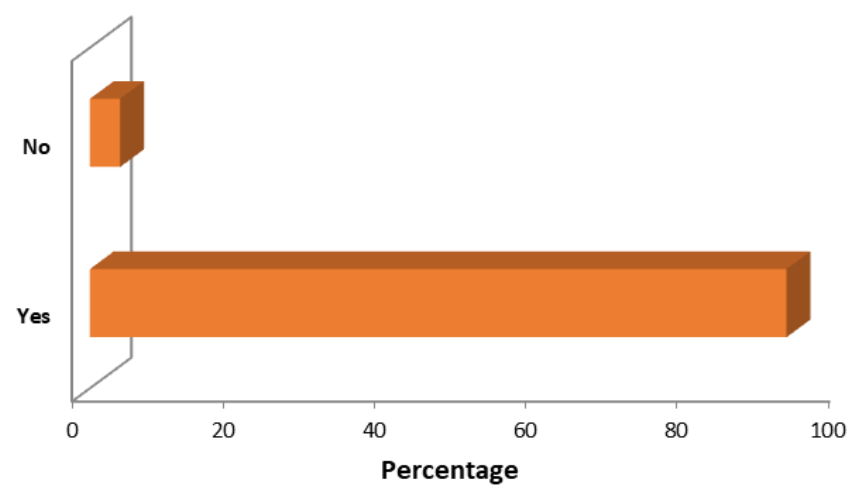

Figure 1 Farmers' knowledge about climate change

$25 \%$ of the farmers were of the opinion that climate change resulted in excessive rainfall experienced, $6.25 \%$ believed that the increase in drought experienced was as a result of climate change while $10.4 \%$ understood climate change to have resulted in decline in yield, $18.8 \%$ said it resulted into crop failure, $16.7 \%$ believed it resulted in increased in pest and disease outbreak while $23 \%$ said it causes high heat waves (Figure 1).

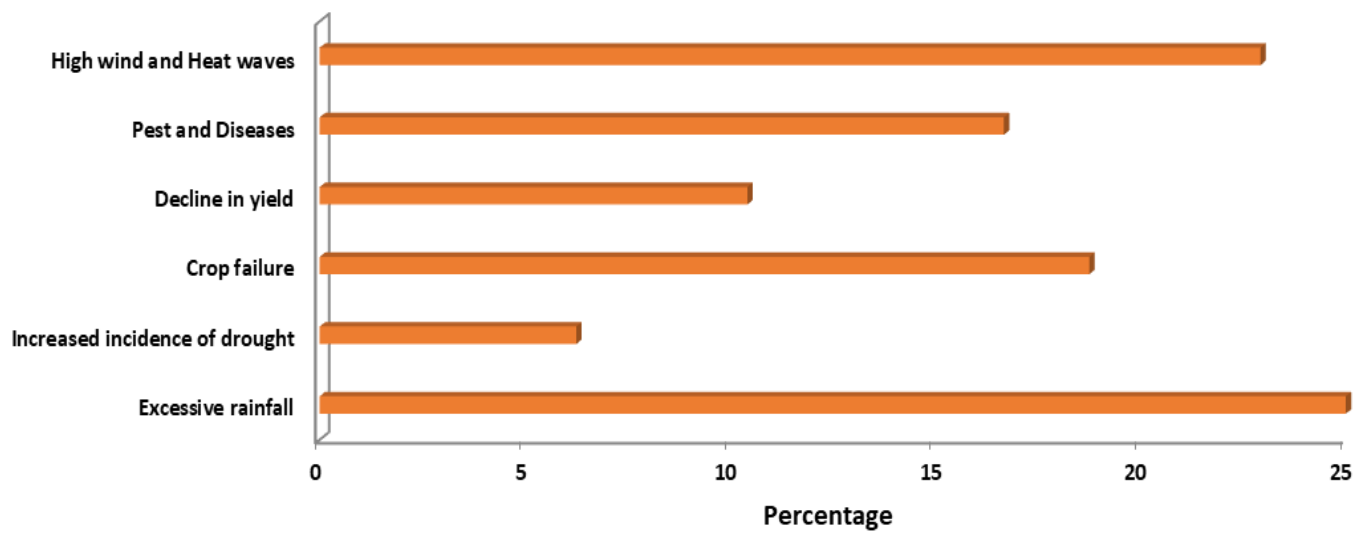

Figure 2 Farmers' perception on climate change

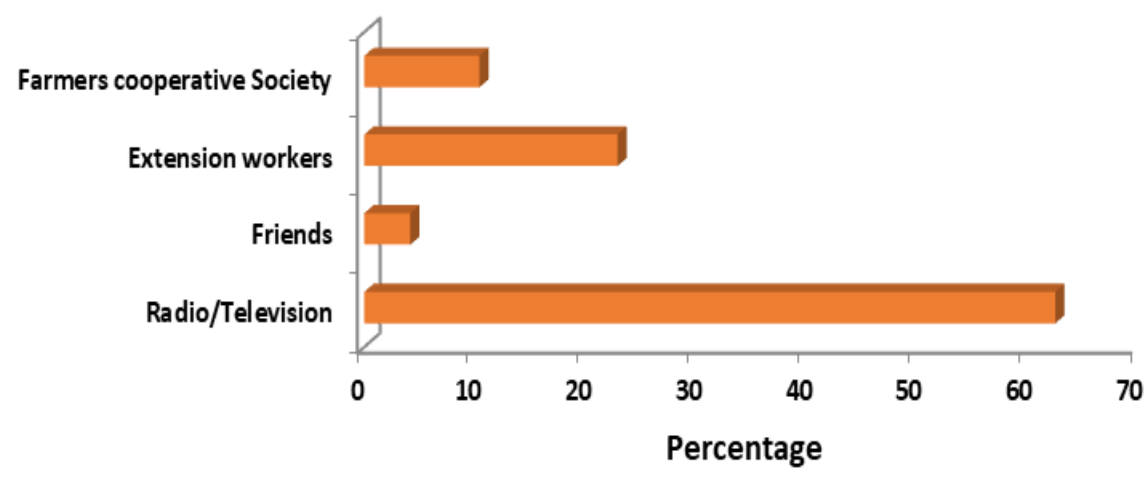

Figure 3 Sources of farmers' information on climate change 
$62.5 \%$ of the farmers from the sampled area got to know about climate change through radio/television, $23 \%$ from extension agents, $4.2 \%$ from friends and $10.4 \%$ from farmers' association. (Figure 3).

Figure 4 showed that $96 \%$ of the farmers were aware of the effect of climate change on cocoa production with only $4 \%$ that does not know that climate change had any effect on cocoa production.

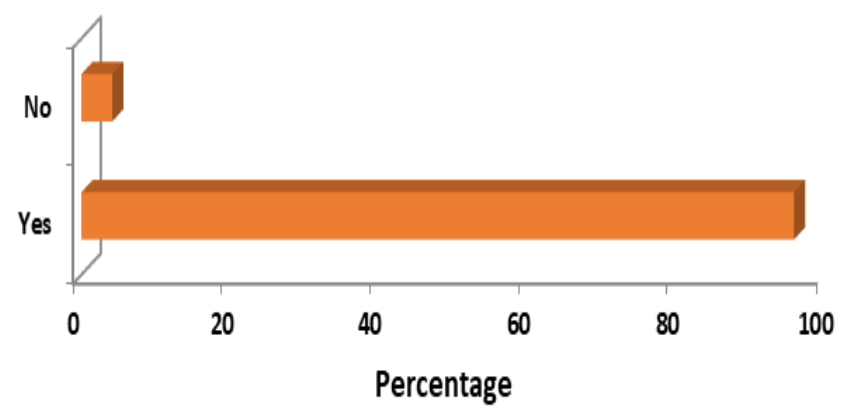

Figure 4 Farmers' knowledge on the effects of climate change on farming system.

Result showed that $65 \%$ of the farmers perceived that climate change negatively imparted on cocoa production while $25 \%$ perceived the effect to be positive (Figure 5).

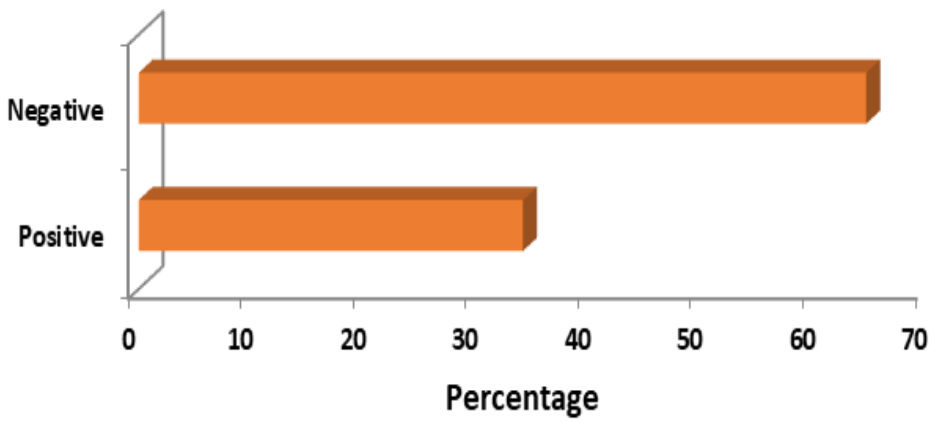

Figure 5 Farmers' perception on the effects of climate change on cocoa plantation

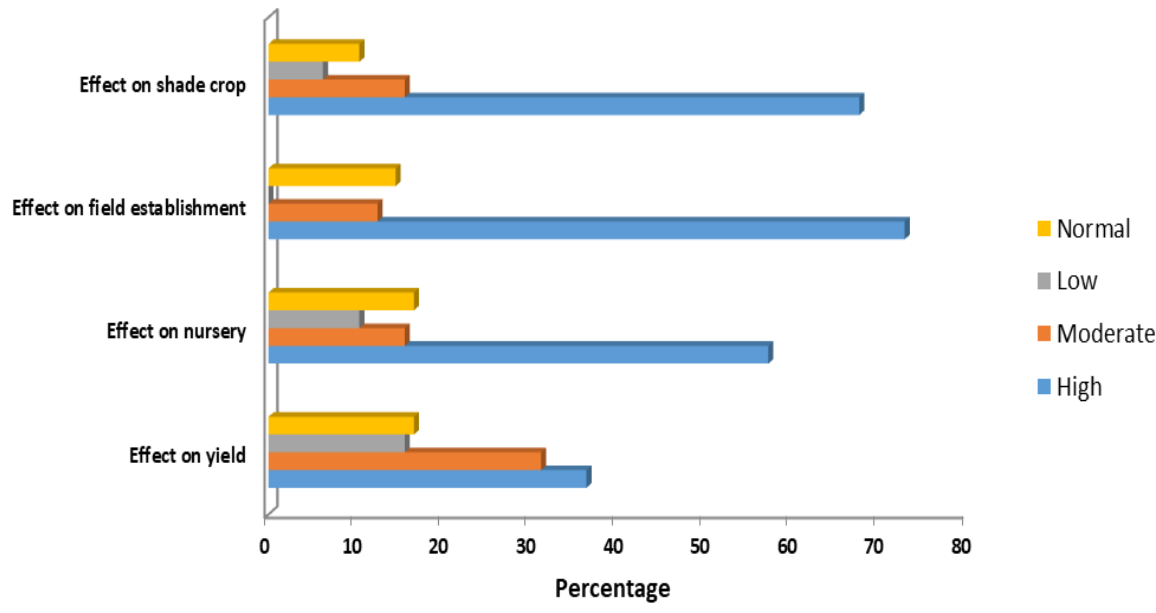

Figure 6 Effects of climate change on cocoa plantation 
The result showed that $68 \%$ of the sampled farmers revealed that the effect of climate change on shade crop is high which resulted in death of seedlings, $15.6 \%$ consider the effect to be moderate, $6.25 \%$ considered it to be low and $10.4 \%$ said it is normal (figure 6). On field establishment, $72.9 \%$ of the respondents indicated that the effect is high resulting in establishment failure, $12.5 \%$ considered it to be moderate and $14.6 \%$ considered it normal (Figure 6). 57.3\% of the sampled farmers also indicated that the effect on climate change on nursery is high which resulted in death of seedlings, $15.6 \%$ considered its effect to be moderate while $16.7 \%$ considered it to be normal (figure 6 ). $36.5 \%$ of the farmers indicate that the effect of climate change on cocoa yield during the season resulting in low yield, while $16.7 \%$ of the farmers considered the effect on yield to be normal, $31.3 \%$ considered it to be moderate and $15.6 \%$ believed it to be low According to [17] farmers who are aware about climate change, its causes and consequences are more likely to adopt adaptation measures and mitigation practices to cope with adverse effect of climate change (figure 6).

\subsection{Effect of climate change on Pest and Diseases of Cocoa}

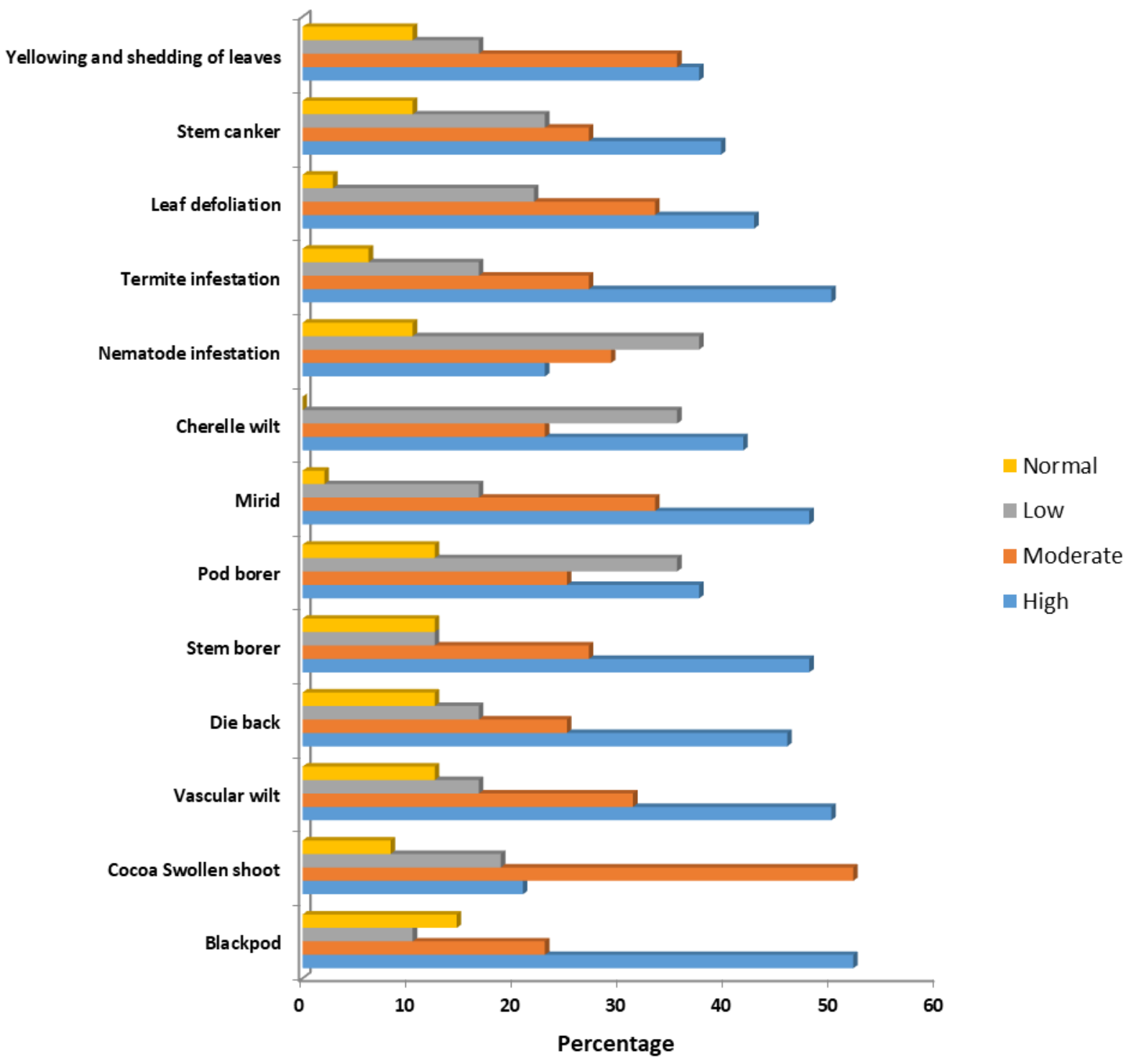

Figure 7 Farmers' perception on the impact of climate change on pests and diseases of cocoa

The cocoa farmers in the sampled area revealed that climate change has greatly imparted on Pests and diseases, with various degrees of effect. From the result on the effect of climate change on pests and diseases, 52\% of the farmers sampled indicated that change in climate resulted in high incidence of the disease, $25 \%$ considered it to be moderate, $10.4 \%$ low and $14.6 \%$ considered its effect on the prevalence of black pod as normal (figure 7). 20.8\% of the farmers believed that the effect of climate change on swollen shoot is high, while $52.1 \%$ believed that the effect is moderate, 
18.8\% considered it as low and $8.3 \%$ said it is low (figure 7). Of all the farmers sampled, 50\% indicated that climate change increases the incidence of vascular wilt disease in the plantation, $8.3 \%$ considered the effect on vascular wilt as normal and 31\% considered it to be moderate (figure 7). 45.8\% of the respondent showed that the effect of climate change on the prevalence of die-back to be high, $25 \%$ considered the effect on die-back as moderate while $12.5 \%$ considered it to be moderate (figure 7). 47.9\% noticed that the effect of climate change on stem borer is higher when compare with $27 \%$ of the respondent which believed that the effect is moderate while $35.5 \%$ indicated that the effect is low (figure 7). $37.5 \%$ of the sampled farmer showed that the impact of climate changed on pod borer to be high, $25 \%$ believed the effect on pod borer is moderate while $35.4 \%$ said its effect on increasing the disease prevalence is low (figure 7). For Mirid, $49.7 \%$ of the respondents indicated that the effect of climate change on mirid prevalence is high, $33.3 \%$ believed the effect is moderate while 2.08 of the respondents believed that the effect is low (figure 7). $41.67 \%$ of the respondents indicate that climate change increased the incidence of cherelle wilt, $35.42 \%$ believed the effect is low while 22.92 indicated that the effect is moderate on cherelle wilt prevalence (figure 7). $37.5 \%$ of the selected farmers showed that the effect of climate change on nematode infection is low, $29.17 \%$ believed that nematode infection as a result of change in climate is moderate while $22.92 \%$ indicated that the effect is high (figure 7 ). $50 \%$ of the respondents were of the opinion that climate change increased the incidence of termite, $27 \%$ of the farmers believed that the effect on termite infestation on the field as a result of climate change is moderate while $16.67 \%$ considered the effect as low (figure 7). The effect of climate change on the prevalence of leaf defoliator was high as indicated by $42.7 \%$ of the respondents, $33.3 \%$ believe the effect on leaf defoliator is low while $21.88 \%$ considered the effect as being low (figure 7). Climate change according to $39.58 \%$ of respondents increased the outbreak of stem canker, $27.08 \%$ believed that the outbreak as a result of change in climate is moderate while $22.9 \%$ indicate that the effect is low (figure 7). Yellowing and shedding of cocoa leaves according to $37.5 \%$ of the respondents is prominent in cocoa plantation, $35.42 \%$ indicated that the yellowing and shedding of leaves is moderate while $10.42 \%$ consider it to be normal (figure 7).

\subsection{Methods adopted by cocoa farmers in adapting and mitigating the effect of climate change in Abia State}

From the result obtained from the respondents, different methods were adopted to adapt and also to mitigate the effect of climate change on cocoa plantation in Abia State. $79.19 \%$ of the farmers conserve soil water to mitigate the effect of climate change, $81.25 \%$ make use of organic matter, $62.5 \%$ plant cocoa varieties that are resistant to pests and diseases, $64.58 \%$ use wetland for plantation, $79.19 \%$ make contour bound around farm to reduce run off, $87.5 \%$ use shade crops to reduce direct sunlight, $75 \%$ of the respondents planted young seedling under existing trees to reduce establishment

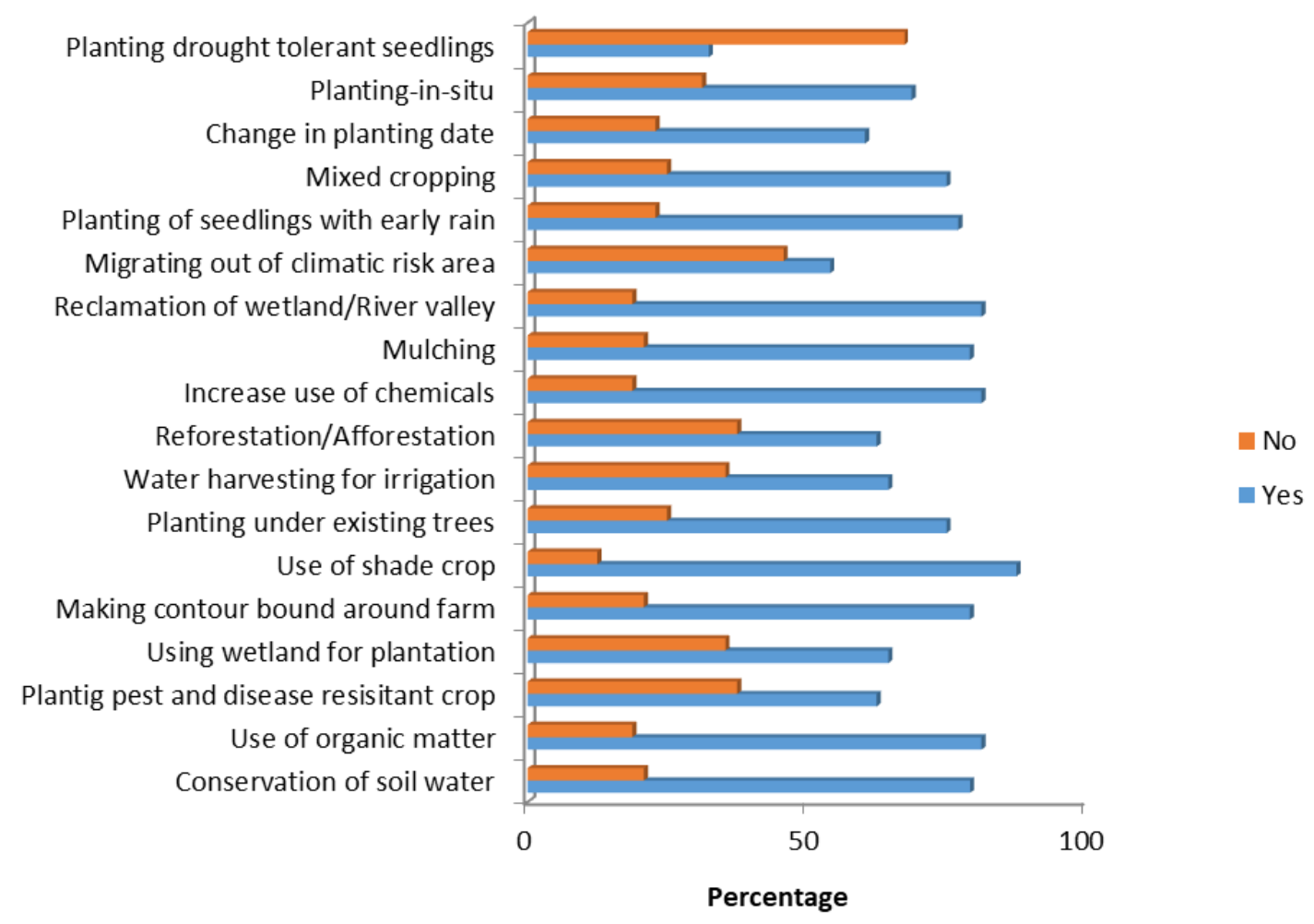

Figure 8 Methods adopted by cocoa farmers in adapting and mitigating the effect of climate change 
failure as a result of adverse effect of change in climate, $64.58 \%$ harvest rain water during the rainy season for irrigating young seedlings, $81.25 \%$ reclaim wetland previously use for growing vegetables for plantation, $62.5 \%$ of the farmers are planting economic trees among the cocoa plants to cushion the effect of climate change on cocoa as the shade crops is also affected by adverse weather condition. $81.25 \%$ of the respondents due to increase in pests and diseases increase the usage of chemicals, $79.17 \%$ mulch the young seedlings to conserve and to reduce soil water loss, $54.17 \%$ migrated out of climate risk area due to repeated field establishment failure to a new locations, $77.08 \%$ transfer seedlings to the field for planting with early rain, since rain could no longer be predicted, $68.75 \%$ of the farmers plant in-situ rather than raising nursery and only $32.5 \%$ plant drought tolerant cocoa seedlings.

\section{Conclusion}

This study has revealed that the high level of awareness exhibited by cocoa farmers concerning climate change in Abia State contributed to adaptation potential which in turns make the farmers less vulnerable towards climate change and in mitigating the effect on pests and disease.

\section{Compliance with ethical standards}

\section{Acknowledgments}

We hereby thank the Management of Cocoa Research Institute of Nigeria for providing fund to carry out this survey under the Cocoa Department.

\section{Disclosure of conflict of interest}

All the authors hereby disclose no conflict of interest/ competing interest

\section{References}

[1] Chikezia C, Ibekwe UC, Ohajianya DO, Orebiyi JS, Henri-Ukoha A, Ukoha II, Osuji MN, Anthony G. Climate change and Percieved Climate Hazard: A trend Analysis in South-East Nigeria. International Journal of Weather, Climate Change and Conservation Research. 2016; 2(1): 1-10.

[2] Onwutuebe CJ. Patriarchy and Women Vulnerability to Adverse Climate Change in Nigeria. 2019.

[3] Shiru, MS, Shahid, S, Alias, N, Chang E-S. Trend Analysis of Droughts during Crop growing seasons of Nigeria. Sustainability. 2018; 10(1): 1-10.

[4] Nkechi G, Onah N, Ali A, Eze E. Mitigating Climate Change awareness in Nigeria. African Traditional Values in fous. Mediterranean Journal of Social Sciences. 2016; 7(6): 299-308.

[5] Anabaraonye B, Okafor, JC, Ikuolegbon JO. Educating farmers and fishermen in rural areas in Nigeria on Climate Change mitigation and Adaptation of Global Sustainability. International Journal of Scientific Engineering Research. 2019; 10(4): 1391-1398.

[6] BNRCC (Building Nigeria's Response to Climate Change). National Adaptation Strategy and Plan of Action on Climate Change for Nigeria (NASPA-CCN). Prepared for the Federal Ministry of Environment Spacial Climate Change Unit. 2011.

[7] Haider H. Climate Change in Nigeria. Impact and Responses. K4D Helpdesk Report 675, Brighton, UK: Institute of Development Studies. 2019; 1-38.

[8] Nwafor JC. Global Climate Change. The driver of multiple causes of food intensity in Sb-Sharan Africa. In International Conference on Climate Change and Economic Sustainability. Nnamdi Azikwe University, Enugu, Nigeria. 2007; 12-14.

[9] Ogbuabor JE, Egechukwu EI. The Impact of Climate Change o the Nigeria Economy. International Journal of Energy Economics and Policy. 2017; 7(2): 217-223.

[10] Amanchukwu RN, Amadi-Ali T, Ololube NP. Climate Change Education in Nigeria: The Role of Curriculum Review. Journal of Education. 2015; 5(3): 71-79.

[11] Oladipo E. Towards enhancing the adaptive capacity of Nigeria: a review of the country's state of preparedness for climate change adaptation. Heinrich Boll Foundation, Nigeria. 2010. 
[12] Akande A, Costa AC, Mateu J, Henriques R. Geospatial Analysis of Extreme Weather Events in Nigeria (1985-2015) Using Self-Organizing Maps. Advances in Meteorology. 2017.

[13] Oyekale AS, Bolaji MB, Olowa OW. The Effects of Climate Change on Cocoa Production and Vulnerability Assessment in Nigeria. Agricultural Journal. 2009; 4(2): 77-85.

[14] Oseni JO. Effect of Climate Change on Cocoa Production in Ondo State Nigeria. Conference paper presented in Impact of Climate Change on Agriculture Conference in Rabat, Morocco. December 6-7 2011.

[15] Raufu MO, Kibirige D, Singh AS. Percieved Effect of Climate Change on Cocoa Production in South-Western Nigeria. International Journal of Development and Sustainability. 2015; 4(5): 529-536.

[16] Codjoe FNY, Ocansey CK, Boaeng OD, Ofori I. Climate Change Awareness and Coping Strategies of Cocoa farmers in Rural Ghana. Journal of Biology Agriculture and Healthcare. 2013; 3(2).

[17] Ojemade AC, Ogonna OO, Bankole AS, Akagbosu BE, Osifo M. (2018). Climate Change and Perception among Oil Palm Farmers in Abia State Nigeria. In Proceedings: Annual Conference Agricultural Society of Nigeria. Agricultural Research Council of Nigeria, Abuja 22-26 October, 2018; 1084-1089. 